\title{
International Journal of Development Education and Global Learning
}

Article

\section{A sour taste in your mouth: consumer privileges and the socio-ecological imperatives of chocolate as pedagogy}

\author{
Bob Manteaw iD \\ Center for Climate Change and Sustainability Studies, University of Ghana, Ghana; rmanteaw@ug.edu.gh
}

Submission date: 10 March 2021; Acceptance date: 8 August 2021; Publication date: 14 December 2021

\section{How to cite}

Manteaw, B. (2021) 'A sour taste in your mouth: consumer privileges and the socio-ecological imperatives of chocolate as pedagogy'. International Journal of Development Education and Global Learning, 13 (2), 109-21. DOI: https://doi.org/10.14324/IJDEGL.13.2.04.

\section{Peer review}

This article has been peer-reviewed through the journal's standard double-blind peer review, where both the reviewers and authors are anonymised during review.

\section{Copyright}

2021, Bob Manteaw. This is an open-access article distributed under the terms of the Creative Commons Attribution Licence (CC BY) 4.0 https://creativecommons.org/licenses/by/4.0/, which permits unrestricted use, distribution and reproduction in any medium, provided the original author and source are credited • DOI: https://doi.org/10.14324/IJDEGL.13.2.04.

\section{Open access}

International Journal of Development Education and Global Learning is a peer-reviewed open-access journal.

\begin{abstract}
This article describes how I use autoethnography as a methodological approach to display the multiple layers of my consciousness as a critical global sustainability educator. I use writing to demonstrate how my reflective processes on my work with chocolate as pedagogy in schools facilitate an exploration of the philosophical and pedagogical underpinnings of what it means and what it takes to educate for sustainability and global awareness and in culturally diverse settings. My desire here is to share insights by writing, describing, examining and theorising my experiences of using chocolate as a pedagogical resource for global education and socio-ecological learning to university students. By using autoethnography, I take the position that writing is a way of knowing, as well as a method of self-discovery and analysis. My aim, therefore, is simple: to use autoethnography as a processual avenue to demonstrate how I used cocoa production in Ghana, and chocolate consumption around the world, to deepen understandings of larger issues around production and consumption, as well as the linkages between learning, society and sustainability. In doing so, I foreground my personal reflective experiences in using chocolate as a teaching resource. Those experiences are objectified as the focus of the research, and I become the subject of research.
\end{abstract}

Keywords global education; chocolate; sustainability; consumption; reflective learning 


\section{Introduction}

All education is environmental education. By what is included or excluded, students are taught that they are part of or part from the natural world. (Orr, 2004: 12)

This article analyses how I use autoethnography as a methodological approach to interrogate my work as a critical global sustainability educator. My desire is to share insights by writing, describing, examining and theorising my experiences of using chocolate as a pedagogical resource to teach global awareness and socio-ecological learning to university students. I take the position that writing is a way of knowing, and a method of self-discovery and analysis (Richardson, 1994; Holt, 2003). In particular, I use writing to demonstrate how my reflective processes on work with chocolate, both in communities and in schools, facilitate an exploration of the philosophical and pedagogical underpinnings of what it means to educate for sustainability in culturally diverse settings.

Following Arjen and Jickling (2002), who argued that teaching in the areas of sustainability and sustainable development requires educators to reflect on their own teaching, this article represents an account of how I used autoethnography as a methodological process to reflect on my performance, also to critically explore different aspects of my teaching approaches and processes. The work represents my personal reflections on enacting a constructivist-informed transgressive pedagogy for teaching sustainability in higher education, and one that responds to current calls for shifts towards innovative, transgressive and disruptive pedagogical forms that are capable of challenging dominant epistemologies and educational discourses that impede the development of sustainability competencies among students (Ayers et al., 2020). Such shifts, in my view, will require intentional pedagogical explorations that will build students' capacities to engage in critical and reflective thinking.

My aim, therefore, is simple: to use chocolate, a globally desired cultural product, as an avenue for deeper understandings of the linkages between learning, society and sustainability, and to inspire bold convictions among other educators to explore pragmatic pedagogical approaches that are capable of challenging the boundaries of teaching and learning, particularly in higher education (Reid and Scott, 2006).

The article is structured as follows: a research design provides a road map into my reflective processes on the specified themes or subjects. The section details the methodological approaches for this work, while providing insights into theoretical underpinnings. This is followed by an account of my motivation for using chocolate as a pedagogical resource, after which I provide a narrative account of how chocolate as pedagogy unfolds in my different classrooms. Here, I highlight the critical importance of the conscious inclusion of socio-ecological, cultural, economic and political issues in education and learning to challenge dominant assumptions and learning forms in schools (Sterling, 2014; Vare and Scott, 2008). The article concludes with a reflection on students' responses and my personal imaginations of how transformation in teaching and learning might look.

\section{Research design}

Writing is also a way of 'knowing' - a method of discovery and analysis. By writing in different ways, we discover new aspects of our topics. (Richardson, 1994: 516)

I approach this work as autoethnography, and as an autobiographical genre of writing and research to display the multiple layers of my consciousness in my work as a critical global sustainability educator (Ellis and Bochner, 2000). Autoethnography, as a social science research method, begins with a descriptive narrative of events and activities that unfold within a particular cultural context, and then develops into a reflective analysis of these events and activities to generate new insights (Wall, 2006). In the case under discussion, the descriptive autoethnographic narrative is shaped by my 
experimental experiences of using global chocolate consumption and cocoa production in Ghana as a pedagogical avenue in various undergraduate and graduate classes that I taught in Canada and the United States.

My teaching and learning experiences with chocolate in these two countries and cultural contexts occurred over a combined period of five years. The research aspect of my different but similar experiences was emergent and was by no means a planned initiative from the outset. Early efforts to situate my difference - otherness - as a Black African from Ghana in my teaching and learning processes in a university in the Pacific Northwest of the United States became instructive, as I learned, to my surprise, that students knew little or nothing at all, not only about Ghana, my native country, but also about Africa more broadly. This sudden realisation of students' dearth of awareness and knowledge about other regions of the world, and their narrow conceptualisation of notions of 'international' filled me, as a critical global sustainability educator, with an urgent desire to act.

That action was to create the needed awareness and to educate students about Ghana and Africa. These were intentional actions that started with storytelling about and with chocolates made in Ghana. These encounters with students then became the focus for research in which I became the subject of research (Bochner and Ellis, 1996; Conquergood, 1991; Richardson, 1992). My experiences became intentional acts characterised by what Ellis and Bochner (2000) describe as 'confessional tales'. Those 'tales' are presented here in writing, as a method of self-discovery and analysis, and, as Richardson (1994) observed, they create the requisite opportunities for self-reflection.

My autoethnographic writing begins, therefore, with a descriptive narrative of events and activities that unfolded over time within my different teaching and learning encounters in various lecture rooms in schools. In all instances, the different encounters were driven by my 'otherness', which prompted various interests and inquisitions into my origins and how I had ended up where I was. My response, inevitably, started with an introduction of my country, Ghana, which also necessarily meant talking frequently and intentionally about cocoa, gold, football and other things.

As interest developed progressively in my stories of Ghana, cocoa and chocolate, I observed also how I could use my various courses - Global Sustainability; Environment, Education and Culture; Place-Based Education; Canadian Society in a Globalized World - at both graduate and undergraduate levels - in the two countries as avenues to foreground cocoa production and chocolate consumption as educational issues. Thus, I began serialising my personal experiences on cocoa farms in Ghana as a premise to tell the larger untold stories about cocoa production in Ghana and the socio-ecological, cultural and political economy considerations that come with it.

I approached these stories not merely as a way of helping my students to learn about Ghana and cocoa production, but as a method of reflection, self-discovery and analysis. They were hopeful stories, as Jones (2013) describes such approaches, which allowed students to live in my world imaginatively, emotionally and reflexively, even if only for a short time. They were experimental approaches which, for a period of over five years of teaching various but interrelated courses in higher education in North American universities, as an African, became the source of my reflective practice (Schön, 1983, 1987) and my confessional tales.

\section{Why chocolate as a pedagogy?}

Chocolate remains one of the most popular and widely consumed confectioneries in the world (Dickson et al., 2016; Grivetti and Shapiro, 2009). Its consumption is worldwide and happens across cultures, but not many consumers around the world know the origins of chocolate, the product they love to enjoy and to celebrate in different ways (Manteaw, 2020; Noble, 2017). About 70 per cent of the world's cocoa is produced exclusively in the West African region, with Ivory Coast, Ghana, Nigeria and Cameroon leading in world production. Ivory Coast and Ghana are by far the largest cocoa-producing countries in the world, providing more than one-third of the traded cocoa in the world (Schroth et al., 2016; Wessel and Quist- 
Wessel, 2015). In countries such as Ivory Coast, Ghana and Cameroon, up to 90 per cent of farmers rely on cocoa for their primary income (Beg et al., 2017).

Cocoa farming, however, is not a particularly lucrative venture, even though the economic livelihoods of so many farmers depend on it. It is fraught with what Noble (2017) describes as 'unequal exchanges', as most cocoa farmers and their families live in conditions of poverty and get by on less than US\$1.25 per day. Even more worrying, perhaps, is the fact that the majority of cocoa farmers around the world, together with their families, suffer varying levels of human rights abuses, ranging from unfair wages, trade exclusions, injustices and poor environmental conditions (Higonnet et al., 2017; Leiter and Harding, 2004; Solis, 2015). Ghana, my native country, had for a long time been the world's leading producer of cocoa until quite recently, when it relinquished that title to its neighbour, Ivory Coast (Wessel and Quist-Wessel, 2015). Ghana has since moved to second place as a global producer of cocoa, and still relies very heavily on cocoa production and sales to support the national economy and development.

However, even as the second largest producer of cocoa in the world, Ghana's cocoa beans remain the quality benchmark on a world cocoa market where quality more than quantity is the yardstick for production supremacy. Thus, Ghana remains the global standard-bearer in the production of cocoa beans of the desired quality for the best chocolates (Peprah, 2019). This fact continues to make Ghanaians proud of what their country offers the world. As Ghana continues to derive tremendous pride from what it offers in terms of cocoa production and chocolate consumption, it is also an ironic fact that not many Ghanaians get the chance to enjoy cocoa products, and especially chocolate (Carr, 2020). This includes the cocoa farmers who work so hard on the plantations to produce the cocoa beans from which chocolate is derived.

Indeed, there are children of cocoa farmers in rural cocoa-producing regions of Ghana who have never seen or eaten chocolate. For most cocoa farmers and their families, chocolate is the last thing they worry about. They would like it if it was readily available to them, but the value they place on their farms and the cocoa beans they produce is derived not from what they get in terms of processed products, nor from the woefully inadequate financial rewards that come with farming, but from the honour of carrying on what they consider to be an intergenerational responsibility, and the dignity in the labour it entails.

While chocolate maintains its popularity as a globally desired cultural product, what gets lost in that reputation, and also in its uniquely sweet taste, are the muted stories of inequality, politics, power, economics, privilege and environmental degradation (ICCO, 2017; Noble, 2017; Off, 2006; Wessel and Quist-Wessel, 2015). These are the untold stories about cocoa production and chocolate consumption; they are the bitter truths which are usually muted in the larger narratives of Ghana's position as a world leader in cocoa production (Bliss, 2011), and also in the joys and pleasures that chocolate presents as a global cultural product of choice (Peprah, 2015; Orla, 2012; Rosenblum, 2006). They are issues that have been left out of school learning processes, particularly as they relate to themes around production and consumption, and how they promote awareness and understanding of social, cultural, economic and political signs in a globalised world.

\section{Learning with and through chocolate}

Beyond teaching students content knowledge and basic academic skills, good teaching aims at developing high-order thinking skills (e.g., critical, and creative thinking), as well as helping students to make ethical choices, and to develop an understanding of other people's concerns. (Alberts, 2010: 105)

My personal connection with cocoa production in Ghana has always made it a lot easier for me to tell the story of chocolate in very compelling ways and use these stories as a launch pad to delve into other complex aspects of cocoa production and global chocolate consumption. This is part of an ethos I have developed in my various classes, where I employ chocolate as a communication tool and a pedagogical resource for global education and sustainability learning (Alberts, 2010). My students, both graduate and 
undergraduate, in universities in Canada and the United States, have called me the 'Chocolate Man', and for good reason: I am African, from Ghana, a global leader in cocoa production, and I use chocolate, a global cultural product, as a pedagogical resource to teach about the world and about issues such as consumption, consumerism, environmental degradation and sustainability.

As a conscious pedagogical approach in my classes, I employ real farm- and community-based stories from Ghana to arouse the curiosity and imagination of students about cocoa production processes and the communities in which they happen. I create awareness and deepen students' understanding of the socio-ecological and politico-economic implications of consumption and consumerism, and cocoa and chocolate remain the vehicle for teaching and learning.

Discussions, however, quickly become open and fluid, to include other related consumer products such as coffee and tea. They also become intense enough to create various levels of discomfort among some students - even more so when discussions extend to issues of privilege, race, power, inequality and social injustices (Zembylas, 2015). When students become increasingly aware of their privileged positions as consumers, and how their consumption practices and choices make them complicit, invariably, in some of the injustices we discuss, they become visibly anxious in their quests for deeper learning and understandings.

\section{Pedagogy of discomfort}

Undoubtedly, these realisations create moments of discomfort among students. Although the original intention was not to create discomfort, as facilitator of the discussions, such moments provide critical teaching opportunities to deepen learning, as well as to facilitate the cultivation of critical reflection and critical thinking among students (Zembylas and Boler, 2002). I have always been particularly careful in guiding students to navigate such moments to avoid unexpected emotional consequences (Nadan and Stark, 2017). I give special attention to their expressed emotions, with a view to managing them to enhance students' abilities to participate effectively in seemingly difficult and unpleasant conversations.

This intentional management of students' emotions and feelings to create positive impacts is described by Boler (1999) as a 'pedagogy of discomfort', and one in which intentional attention is given to students' reactions to the different 'uncomfortable' conversations. Boler and Zembylas (2003) further argue that the special attention given to students' emotions and expressed discomforts aims to develop what they describe as 'emotional habits'. Such habits, once clarified, become pedagogical entry points to deepen students' self-awareness, reflectivity and critical thinking skills. In the process, students' comfort zones are disrupted as they are assisted and encouraged to deconstruct inscribed cultural and emotional terrains which they occupy not by choice, but by virtue of privilege and hegemony.

Such disruptions characterise my approach. However, in using chocolates as a vehicle, I provide an enabling environment in lecture rooms, where critical issues underpinning global production and consumption processes are interrogated. I employ different levels of deliberations and exposures to help students know, understand and appreciate their positions as privileged consumers, and how such positions, and what they entail, contribute to global inequalities, environmental degradation and social injustices in places unknown to them. Such exposures become new knowledge, and they challenge the thinking of students in ways that make it easier for them to develop deeper meanings and understandings of existing linkages between learning, society and sustainability (Reid and Scott, 2006).

\section{Tasting the bitter truth of chocolate}

The journey to accomplish my purpose therefore begins with what I call deliberative dialogue, and here I guide students in my classes, both graduate and undergraduate, literally to taste the bitter truth about cocoa production and chocolate consumption (Alberts, 2010; Bliss, 2011; Lee and Fagan, 2015; Rosenblum, 2006). When it is possible, I bring chocolates made in Ghana to my classes. Students then get the rare opportunity to taste and enjoy the purity of Ghana-made chocolates. While they do, I give a 
narrative account of the history, and the socio-cultural, socio-ecological and politico-economic realities that surround cocoa production in Ghana and the global consumption of chocolate.

Foregrounding chocolate as a learning resource has, therefore, become a quasi-tradition in my classes, and a conscious pedagogical approach to help students come to terms with the socio-cultural dimensions of cocoa production processes in Ghana, and chocolate consumption around the world. I use deliberative exchanges and critical discussions to explore students' cultural connections with chocolate; their awareness of how chocolate is produced; their knowledge of sources of cocoa production; their knowledge of the places of production; and their understanding of the socio-ecological and politicoeconomic ramifications that surround production and consumption processes. I introduce these themes through carefully crafted questioning processes in a very relaxed and accommodative environment that allows students to be fully engaged in the deliberations. These initial discussions eventually culminate in a focused discussion about Ghana, first as my country of origin; second, as a global leader in cocoa production; and third, what this means not just for the people of Ghana, but for Africa broadly.

I situate my 'otherness' in the narratives as a way of providing a lens through which students may view and appreciate my cultural histories. These narratives continue as students enjoy chocolates made in Ghana. In the process, I draw their attention to the fact that, as common and as easily accessible as chocolate is to most of them in the places where they live, there are men, women and children in Ghana who have never seen chocolate, nor ever had the opportunity to enjoy any cocoa product. I emphasise with intentionality that there are children in Ghana - some of them children of cocoa farmers, who help out on cocoa farms to produce cocoa - who have never seen or eaten chocolates (Frydenborg, 2015). As I have indicated, these revelations are purposefully inserted and carefully timed as a climax to the ongoing made-in-Ghana chocolate feast happening in class, and almost consistently in all my classes, students have reacted to them with shock and disgust.

\section{How can a child not eat chocolate?}

With sour tastes in their mouths, literally, students ask almost in unison: Are these chocolates not made in Ghana? Why don't children eat chocolate? How can a child not eat chocolate? Students get bemused into silence upon the revelation about children and chocolate in Ghana and other parts of Africa. They struggle within their own cultural constructs to conceptualise what it means for a child not to have ever seen or eaten chocolate. As instructor and facilitator of the discussions, these moments provide fertile grounds for me to plant the seeds of learning and new knowledge, and they are moments that I relish.

I set out to provide narratives of why and how children in Ghana never get the chance to eat chocolate, and the principal organising purpose of this conversation is to help students to come to terms with some taken-for-granted assumptions, as well as to understand the different interplays of culture, power and privilege in cocoa production and chocolate consumption. Through critical exploration of these issues, I guide students to the political economy around the international cocoa trade, and how issues of power, inequality and unfair trade practices negatively affect the people involved in the production processes on farms (Heijbroek and Konijn, 1995). I challenge students' taken-for-granted assumptions about the things they so casually call 'stuff' by helping them understand production and consumption practices, and underlying issues of power, privilege, political economy and socio-ecology, and how they shape local and global discourses around cocoa production and chocolate consumption (Bello and Mitchell, 2018; Farahmandpur, 2010; ICCO, 2016, 2017).

More importantly, I also help students come to terms with their unrecognised or underestimated status as privileged consumers, and what that means for their relationships with the sources of the products that they so casually consume as 'stuff'. Such insights help students to hesitantly understand how and why their cultural valuation of chocolate is different from that of others in distant places. It also helps them to appreciate why some children do not eat chocolates as they do. Students remain shocked by these revelations, and they maintain expressions of bewilderment to signal disgust, discomfort, surprise, guilt 
or even disagreement with some of the explanations I provide to their varied questions. However, they recover quickly from their early shock to ask more piercing questions about why children do not eat chocolate in Ghana. For the most part, these questions are culturally encumbered, as they expose their identities as privileged consumers totally disconnected from the social and cultural realities of distant places from where most of what they consume originates.

Again, as instructor, such moments of questioning, intense exchanges between myself and students, and the emotions and discomfort they generate, become particularly instructive for the purpose of my work and the learning process (Ramsden, 1992). It is through such exchanges that I actualise the pedagogy of discomfort in the process (Boler, 1999; Boler and Zembylas, 2003). I manage these moments with deliberate attention paid to students' expressed viewpoints and concerns. These concerns and how they are expressed constitute their 'emotional habits', which, ultimately, become entry points for the deeper and more meaningful engagement. More importantly, I use these habits to quell anxieties and the possibility of unintended consequences, especially as they relate to the creation of stereotypes about Ghana, and Africans generally. This approach has proved fulfilling on many occasions, as it enhances awareness creation and deeper learning about aspects of the world other than those which students know. It also helps students enhance their critical thinking skills, as well as facilitates the cultivation of multiple perspectives and self-awareness (Kraft, 2002).

\section{Why do children work on cocoa farms?}

I always spend quite a bit of time talking to students about my personal experiences working on my grandparents' cocoa farms in Ghana, and I use these narratives to help students understand how and why children play certain roles on cocoa farms. These discussions have always been contentious and difficult to lead. However, I approach them carefully and aim to guide students to understand notions of child labour and cultural interpretations of children's role on cocoa farms. Students become intensely curious and eager to know more about cocoa production in Ghana, and in particular why some children have to work on cocoa farms and why that is not considered an abuse of the rights of children.

Again, as facilitator of the discussions, this topic has always been challenging. I struggle not only with how to present it, but also how to avoid creating reasons for wrong and stereotypical impressions. Every expressed concern or question from students provides new insights and learning moments which challenge me to consider new strategies to improve on my function (Hamza and Griffith, 2006). That said, it is also a topic that I have found particularly influential in its ability to help students imagine other cultures, and, more so, in how it helps students to better appreciate their own privileges as innocent consumers. I dispel their concerns about child abuse by letting them know that there are laws in Ghana, and that Ghana is a law-abiding country.

I explain that issues of child labour dominate discourses about cocoa production and chocolate consumption around the world (Balch, 2018). However, it is also a fact that a lot of these notions and discourses, particularly as they relate to Ghana, are disconnected from local tradition and cultural practices. I support this by letting students know and understand that most cocoa farmers believe that farming is a skilled trade that should be learned very early on in the lives of children. They therefore feel a personal responsibility to pass this skill on to their children. As it was with my own time on my grandparents' cocoa farms, most children also feel obliged to help out on farms, not as work, but as education, training and skill development.

Notions of child labour and child abuse have in recent times become major issues in cocoaproducing countries including Ghana, as many see children's activities on cocoa farms as child labour and abuse (Balch, 2018; Laird, 2002; Solis, 2015). Strict rules have been introduced about what children can and cannot do on farms, and many governments, including the government of Ghana, have become particular about the roles of children on cocoa farms. The rules are very strict and, in different ways, are linked to sustainability and quality standards, which ultimately has market implications. I use these 
moments as opportunities to talk about issues of fair trade and eco-labelling, which are a common feature in chocolate packaging and consumption (Vecchio and Annunziata, 2015). I also take advantage of this to introduce students to issues of standards in production, and how they are increasingly being employed as sustainability tools.

The rules about child labour also emphasise the critical importance of children being in school and playing only occasional defined and permissible roles on cocoa farms. Most children of cocoa farmers now spend a good part of their time in school, rather than on farms. They see their future in vocations other than cocoa farming, but also feel a sense of loyalty towards the occupation of their parents and generations before them. Much as children of cocoa farmers never perceived their roles on their parents' farms as abusive, they also have come to appreciate the fact that there is life beyond cocoa farming, and that the only way to explore that alternative is to stay in school and pursue education.

Insistence on formal education for farm-based children has introduced them to new and better possibilities, which, at the same time, have brought new and unanticipated threats to the future sustainability of cocoa production and chocolate consumption. As children of farmers see their future away from cocoa farming and in school, new challenges are emerging as farmers begin to get old without a ready succession plan. The questions then are: What happens on cocoa farms when parents have grown old and the children are away working in cities and towns in other professions? What happens also to the world's insatiable appetite for chocolate and other cocoa products? These are critical questions that I challenge students to consider and to explore answers. While they do, I also challenge them to think about what that might mean for chocolate consumption.

Discussions on the topic of child labour always animate the class. It is a difficult topic, but one that most students find particularly interesting and absorbing. Students are always unanimous in their condemnation of child labour and, as facilitator of the discussions, with cultural roots in both worlds Africa and the Global North - I am able to appreciate their positions and acknowledge their sentiments. I show open support in our collective condemnation of child labour of any form or kind anywhere in the world; however, as part of the underlying purpose of the approach, I also use such discussions to open the eyes of students to the realities of other people in distant places by highlighting underlying issues of cultural relativity.

Thus, as unjustifiable as child labour may seem to students and the cultures to which they belong, I try to point out the underlying cultural nuances and complexities of such activities by explaining how and why some of what they perceive as child labour in Ghana and other such places could not in the strictest sense be considered as such by local people (Isern, 2006). In other words, I try to get them to understand that in many instances in Ghana, as elsewhere, children working on cocoa farms is less a case of exploitation, and more a case of necessity for vocational training and succession planning and inheritance. Cocoa farm ownership has significant meanings to farmers and their families. It is an intergenerational project which requires that children be deliberately trained and inducted to take over in the long run. Discussions about child labour and child rights are always intense. They enhance students' imagination about life on the cocoa farms. They also help students make sense of the realities of other people's cultures, no matter how conflicting they are with their standpoints or cultures.

\section{How does chocolate consumption impact the environment?}

Our discussions advance to include how cocoa production and increasing world demand for chocolate and other cocoa products affect local environments in Ghana and other such places. Specifically, I aim such discussions at developing deeper awareness among students of the threats of environmental degradation and climate change to the production of cocoa and to the consumption of chocolate. While the primary motive is to draw students' attention to the indirect connections that exist between their consumption habits and environmental degradation in cocoa-producing areas of the world such as Ghana, I also use 
such discussions to foreground what Rice (2007) describes as 'ecologically unequal exchanges' and the environmental costs associated with such exchanges.

I situate such discussions within the broader context of international trade and the demand and supply dynamics that define such processes. I use cocoa production in Ghana, and the insatiable appetite for chocolate consumption around the world, to explain how such demands and, of course, farmers' dependence on cocoa production as a sole source of livelihood, leads to aspirational farm expansions, which eventually put increased pressures on forest lands and cause environmental degradation (Sandlin and McLaren, 2010; Ntiamoah and Afrane, 2008). Increasing world demand for cocoa, and governments' desire to earn more foreign exchange to support national economies, have become some of the underlying reasons for government-led initiatives that encourage increases in cocoa production (Wessel and Quist-Wessel, 2015). Such initiatives are common, and they ultimately put tremendous pressures on farmers to expand cultivation sites into new areas, which also mean degrading forests to make way for such expansions.

Considering the roles of forests in climate change, and the extent to which cocoa farms are encroaching on forest lands, it is no wonder that the impact of climate change continues to be felt in most communities in Ghana and around the world (Gockowski and Sonwa, 2010). This is also against the background of observed rising temperatures and hydro-climatic variability and change, which are already threatening the future of cocoa production in Ghana, and the livelihoods of all involved in the production and consumption chain (Schroth et al., 2016). The international cocoa trade and increasing demand for cocoa can only bear part of the blame for climate change and associated impacts on cocoa farms, but there are also some externalized ramifications that go largely unnoticed.

In many instances, the environmental costs which arise out of production processes are unequally and unfairly borne by poorer countries such as Ghana, where primary commodities such as cocoa are produced (Bunker, 1985; Emmanuel, 1972; Hornborg, 1998; Rice, 2007; Jorgenson and Clark, 2009; Konstantas et al., 2018). When I explain these seemingly complex issues to students, they usually remain quiet for the most part as I share the stories. In their quietness, I see them reflect deeply on the issues; they begin to appreciate the connection between consumption and environmental degradation, and to come to terms with their unrecognised roles in the process. Very often in my classes, and with remnants of the chocolates from Ghana still in their hands or mouths, they ask very despondently: Is there anything we can do? What can we do to change things? The consistency of such questions, and the familiarity of expressed curiosity over time, have served as my motivation to continue to use chocolate as a pedagogical tool to challenge the bounds of teaching and learning by bringing social, cultural political and environmental issues into the mix in the learning process.

The questions from students are genuine: they are not just evidence of learning; they also represent how authentic learning challenges transformational desires and actions. I connect emerging issues around production and consumption processes to larger global political economy and political ecology issues by demonstrating to students how their consumption of ordinary products such as chocolate connects them to different places around the world, and how such connections also sometimes make them complicit in the things they so desire to change. I remind them of what Greenwood (2010: 193) wrote:

Everyday consumption and participation in the money economy connects consumers to a wide range of places where other people live and work and die. Consumption begins with the biophysical and culturally shaped places of production, and social and environmental conditions surrounding human labor. Extraction, production, consumption, and waste - each of these processes and the points in between, connects consumers to a great many places and socioecological conditions that are generally and sometimes purposefully obscured from the consumer.

Students' reactions give me significant cause to consciously reflect on my approach and how such approaches lead eventually to expression of desire to do something about the situation. 


\section{'What can we do to change things?'}

Reflection needs to be more than a consideration of the technical and organisational aspects of presenting problems. It should also mean raising social, political, and cultural issues, questioning purposes and intentions, and if necessary, challenging the assumptions and taken-for-granteds on which organisational policies and practices are based. (Reynolds, 2011: 8)

The question 'What can we do to change things?' has remained profoundly influential in the evaluation of my approach and performance. It challenged my thinking and influenced my next course of action. More importantly, perhaps, it also helped me gain deeper insights into my seemingly transgressive pedagogical approach, and in ways that enhance my reflectivity and critical appreciation of what is taught and not taught in schools (Johns, 2009; Ghanizadeh, 2017). As I continue to reflect on the question of what students could do to possibly change things, the more convinced I have become that dominant forms of education and learning, especially in higher education, require radical transformation to confront and address the sustainability challenges of the time (Fien, 2002). That conviction reminds me of Orr's (1992: 85) observation that:

Not only are we failing to teach the basics about the earth and how it works, but we are in fact teaching a large amount of stuff that is simply wrong. By failing to include ecological perspectives in any number of subjects, students are taught that ecology is unimportant for history, politics, economics and so forth.

This, to me, is profound and instructive as to why and how radical shifts in contemporary educational thinking and practice are an urgent imperative (Burns, 2015).

Failure to make those shifts, as Orr (1992) implies, perpetuates the current bifurcation of school learning into economic and non-economic subjects or disciplines, where the inclusion of socio-ecological and cultural considerations in teaching and learning is perceived largely as being low-status knowledge with little or no market value (Bowers, 1997). These bifurcations not only dictate what is learned in schools, they also determine what is excluded and what kind of knowledge has market advantage.

It is from such perspective that narrow economic rationalities, techno-scientific imperatives and market obsessions are forcefully prioritised to dominate contemporary educational thinking and practice (Gruenewald and Manteaw, 2007; Hill, 2010; Sandlin, 2010). For anything to change, as students in my classes desperately ask, there is an urgent need for a redirection of education, especially in higher education, to focus not only on what is learnt in schools, but also on how what is learned is taught (Barth, 2015; Wiek et al., 2013).

\section{Declarations and conflicts of interest}

\section{Conflicts of interest statement}

The author declares no conflicts of interest with this work. All efforts to sufficiently blind the author during peer review of this article have been made.

\section{Consent for publication statement}

The author declares that participants' informed consent to publication of findings - including photos, videos and any personal or identifiable information - was secured prior to publication.

\section{References}

Alberts, H.C. (2010) 'Using cocoa and chocolate to teach human geography'. Journal of Geography, 109 (3), $105-12$. https://doi.org/10.1080/00221341.2010.485279. 
Arjen, E.J. and Jickling, B. (2002) "'Sustainability" in higher education: From doublethink and newspeak to critical thinking and meaningful learning'. International Journal of Sustainability in Higher Education, 3 (3), $221-32$. https://doi.org/10.1016/S0952-8733(02)00003-X.

Ayers, J., Bryant, J. and Missimer, M. (2020) 'The use of reflective pedagogies in sustainability leadership education - A case study'. Sustainability, 12 (17), 6726. https://doi.org/10.3390/su12176726.

Balch, O. (2018) 'Child labor: The dark truth behind chocolate production'. Raconteur, 20 June. Accessed 3 May 2020. https://www.raconteur.net/business-innovation/child-labour-cocoa-production.

Barth, M. (2015) Implementing Sustainability in Higher Education: Learning in an age of transformation. New York: Routledge.

Beg, M.S., Ahmad, S., Jan, K. and Bashir, K. (2017) 'Status, supply chain and processing of cocoa - A review'. Trends in Food Science and Technology, 66, 108-16. https://doi.org/10.1016/j.tifs.2017.06.007.

Bello, T. and Mitchell, M.I. (2018) 'The political economy of cocoa in Nigeria: A history of conflict or cooperation?'. Africa Today, 64 (3), 71-91. https://doi.org/10.2979/AFRICATODAY.64.3.04.

Bliss, S. (2011) 'Bittersweet chocolate: From ground to mouth'. Geography Bulletin, 43 (4), 20.

Bochner, A.P. and Ellis, C. (1996) 'Introduction: Talking over ethnography'. In C. Ellis and A.P. Bochner (eds), Composing Ethnography: Alternative forms of qualitative writing. Oxford: Altamira Press, 13-45.

Boler, M. (1999) Feeling Power: Emotions and education. New York: Routledge.

Boler, M. and Zembylas, M. (2003) Discomforting Truths: The emotional terrain of understanding difference. New York: Routledge.

Bowers, C.A. (1997) The Culture of Denial: Why the environmental movement needs a strategy for reforming universities and public schools. Albany: State University of New York Press.

Bunker, S.G. (1985) Under-Developing the Amazon: Extraction, unequal exchange, and the failure of the modern state. Chicago: University of Chicago Press.

Burns, H.L. (2015) 'Transformative sustainability pedagogy: Learning from ecological systems and indigenous wisdom'. Journal of Transformative Education, 13 (3), 259-76. https://doi.org/10.1177\%2F1541344615584683.

Carr, T. (2020) 'The bitter side of cocoa production'. Sapiens, 13 February. Accessed 5 May 2020. https://www.sapiens.org/ culture/cocoa-production/.

Conquergood, D. (1991) 'Rethinking ethnography: Towards a critical cultural politics'. Communications Monographs, 58 (2), 179-94. https://doi.org/10.1080/03637759109376222.

Dickson, H., Kavanagh, D.J. and MacLeod, C. (2016) 'The pulling power of chocolate: Effects of approach-avoidance training on approach bias and consumption'. Appetite, 99, 46-51. https://doi.org/10.1016/j.appet.2015.12.026.

Ellis, C. and Bochner, A. (2000) 'Autoethnography, personal narrative, reflexivity: Researcher as subject'. In N.K. Denzin and Y.S. Lincoln (eds), Handbook of Qualitative Research. 2nd ed. Thousand Oaks, CA: Sage, 733-68.

Emmanuel, A. (1972) Unequal Exchange: A study of the imperialism of trade. New York: Monthly Review Press.

Farahmandpur, R. (2010) 'Teaching against consumer capitalism in the age of commercialism and corporatization of public education'. In J. Sandlin and P. McLaren (eds), Critical Pedagogies of Consumption: Living and learning in the shadow of the shopocalypse. London: Routledge, 58-66.

Fien, J. (2002) 'Advancing sustainability in higher education: Issues and opportunities for research'. Higher Education Policy, 15 (2), 143-52. https://doi.org/10.1016/S0952-8733(02)00005-3.

Frydenborg, K. (2015) Chocolate: Sweet science and dark secrets of the world's favorite treat. New York: Houghton Mifflin Harcourt.

Ghanizadeh, A. (2017) 'The interplay between reflective thinking, critical thinking, self-monitoring, and academic achievement in higher education'. Higher Education, 74, 101-14. https://doi.org/10.1007/s10734-016-0031-y.

Gockowski, J. and Sonwa, D. (2010) 'Cocoa intensification scenarios and their predicted impact on CO2 emissions, biodiversity conservation, and rural livelihoods in the Guinea rain forest of West Africa'. Environmental Management, 48 (2), 307-21. https://doi.org/10.1007/s00267-010-9602-3.

Greenwood, D.A. (2010) 'Chocolate, place, and a pedagogy of consumer privilege'. In J. Sandlin and P. McLaren (eds), Critical Pedagogies of Consumption: Living and learning in the shadow of the shopocalypse. London: Routledge, 193-200.

Grivetti, L.E. and Shapiro, H.Y. (2009) Chocolate: History, culture, and heritage. Hoboken, NJ: John Wiley and Sons.

Gruenewald, D.A. and Manteaw, B.O. (2007) 'Oil and water still: How No Child Left Behind limits and distorts environmental education in US schools'. Environmental Education Research, 13 (2), 171-88. https://doi.org/10.1080/ 13504620701284944.

Hamza, M.K. and Griffith, K.G. (2006) 'Fostering problem-solving and creative thinking in the classroom: Cultivating a creative mind'. National Forum of Applied Educational Research Journal-Electronic, 9 (3), 1-32. Accessed 21 August 2021. https://tinyurl.com/44v769sh.

Heijbroek, A.M.A. and Konijn, R.J. (1995) The Cocoa and Chocolate Market. Utrecht: Rabobank Nederland.

Higonnet, E., Bellantonio, M. and Hurowitz, G. (2017) Chocolate's Dark Secret: How the cocoa industry destroys national parks. Mighty Earth. Accessed 20 August 2021. http://www.mightyearth.org/wp-content/uploads/2017/09/chocolates_ dark_secret_english_web.pdf. 
Hill, D. (2010) 'Class, capital, and education in this neoliberal and neoconservative period'. In S. Macrine, P. McLaren and D. Hill (eds), Revolutionizing Pedagogy: Education for social justice within and beyond global neo-liberalism. New York: Palgrave Macmillan, 119-43.

Holt, N.L. (2003) 'Representation, legitimation, and autoethnography: An autoethnographic writing story'. International Journal of Qualitative Methods, 2 (1), 18-28. https://doi.org/10.1177\%2F160940690300200102.

Hornborg, A. (1998) 'Towards an ecological theory of unequal exchange: Articulating world system theory and ecological economics'. Ecological Economics, 25 (1), 127-36. https://doi.org/10.1016/S0921-8009(97)00100-6.

ICCO (International Cocoa Organization) (2016) May 2016 Quarterly Bulletin of Cocoa Statistics. Accessed 20 August 2021. https://www.icco.org/may-2016-quarterly-bulletin-of-cocoa-statistics/.

ICCO (International Cocoa Organization) (2017) World Cocoa Bean Production, Grindings and Stocks. Accessed 5 April 2018. https://www.fairtrade.net/fileadmin/user_upload/content/2009/standards/ documents/generic-standards/ TS_EN.pdf.

Isern, J. (2006) 'Bittersweet chocolate: The legality and ethics of child labor in cocoa production in Côte d'Ivoire'. Journal of Applied Management and Entrepreneurship, 11 (1), 115-32.

Johns, C. (2009) Becoming a Reflective Practitioner. Chichester: John Wiley and Sons.

Jones, M. (2013) 'Traversing No Man's Land in search of an(other) identity: An autoethnographic account'. Journal of Contemporary Ethnography, 42 (6), 745-68. https://doi.org/10.1177\%2F0891241613484356.

Jorgenson, A.K. and Clark, B. (eds) (2009) 'Ecologically unequal exchange in comparative perspective: A brief introduction'. International Journal of Comparative Sociology, 50 (3-4), 211-4. https://doi.org/10.1177\%2F0020715209105139.

Konstantas, A., Jeswani, H.K., Stamford, L. and Azapagic, A. (2018) 'Environmental impacts of chocolate production and consumption in the UK'. Food Research International, 106, 1012-25. https://doi.org/10.1016/j.foodres.2018.02.042.

Kraft, N.P. (2002) 'Teacher research as a way to engage in critical reflection: A case study'. Reflective Practice, 3, $175-89$. https://doi.org/10.1080/14623940220142325.

Laird, S. (2002) 'The 1998 children's act: Problems of enforcement in Ghana'. British Journal of Social Work, 32 (7), 893-905. https://doi.org/10.1093/bjsw/32.7.893.

Lee, S.M. and Fagan, J.M. (2015) Bitter Truth Behind Sweet Chocolate. Accessed 4 September 2021. https://rucore. libraries.rutgers.edu/rutgers-lib/47845/.

Leiter, J. and Harding, S. (2004) 'Trinidad, Brazil, and Ghana: Three melting moments in the history of cocoa'. Journal of Rural Studies, 20 (1), 113-30. https://doi.org/10.1016/S0743-0167(03)00034-2.

Manteaw, B. (2020) 'Consumer privileges and the sociocultural dimensions of production and consumption'. In P. Molthan-Hill, H. Luna, T. Wall, H. Puntha and D. Baden (eds), Storytelling for Sustainability in Higher Education: An educator's handbook. Abingdon: Routledge, 193-204.

Nadan, Y. and Stark, M. (2017) 'The pedagogy of discomfort: Enhancing reflectivity on stereotypes and bias'. British Journal of Social Work, 47, 683-700. https://doi.org/10.1093/bjsw/bcw023.

Noble, M.D. (2017) 'Chocolate and the consumption of forests: A cross-national examination of ecologically unequal exchange in cocoa exports'. Journal of World-Systems Research, 23 (2), 236-68. https://doi.org/10.5195/ JWSR.2017.731.

Ntiamoah, A. and Afrane, G. (2008) 'Environmental impacts of cocoa production and processing in Ghana: Life cycle assessment approach'. Journal of Cleaner Production, 16 (16), 1735-40. https://doi.org/10.1016/j.jclepro.2007.11.004.

Off, C. (2006) Bitter Chocolate: Investigating the dark side of the world's most seductive sweet. Brisbane: University of Queensland Press.

Orla, R. (2012) Chocolate Nations: Living and dying for cocoa in West Africa. London: Zed Books.

Orr, D.W. (1992) Ecological Literacy: Education and the transition to a postmodern world. Albany: State University of New York Press.

Orr, D.W. (2004) Earth in Mind: On education, environment, and the human prospect. Washington, DC: Island Press.

Peprah, K. (2015) 'Sustainability of cocoa farmers' livelihoods: A case study of Asunafo District, Ghana'. Sustainable Production and Consumption, 4, 2-15. https://doi.org/10.1016/j.spc.2015.09.001.

Peprah, K. (2019) 'Cocoa plant, people and profit in Ghana'. In P. Aikpokpodion (ed.), Theobroma Cacao: Deploying science for sustainability of global cocoa economy. IntechOpen. https://doi.org/10.5772/intechopen.81991.

Ramsden, P. (1992) Learning to Teach in Higher Education. London: Routledge.

Reid, A. and Scott, W. (2006) 'Researching education and the environment: Retrospect and prospect'. Environmental Education Research, 12 (3-4), 571-87. https://doi.org/10.1080/13504620600917669.

Reynolds, M. (2011) 'Reflective practice: Origins and interpretations'. Action Learning: Research and practice, 8 (1), 5-13. https://doi.org/10.1080/14767333.2011.549321.

Rice, J. (2007) 'Ecological unequal exchange: Consumption, equity, and unsustainable structural relationships within the global economy'. International Journal of Comparative Sociology, 48 (1), 43-72. https://doi.org/10.1177\% 2F0020715207072159.

Richardson, L. (1992) 'The consequences of poetic representation'. In C. Ellis and M.G. Flaherty (eds), Investigating Subjectivity: Research on lived experience. Thousand Oaks, CA: Sage, 125-37. 
Richardson, L. (1994) 'Writing: A method of inquiry'. In N.K. Denzin and Y. Lincoln (eds), Handbook of Qualitative Research. London: Sage, 516-29.

Rosenblum, M. (2006) Chocolate: A bittersweet saga of dark and light. New York: North Point Press.

Sandlin, J.A. (2010) 'Learning to survive the "Shopocalypse": Reverend Billy's anti-consumption "pedagogy of the unknown"'. Critical Studies in Education, 51 (2), 295-311. https://doi.org/10.1080/17508487.2010.508809.

Sandlin, J.A. and McLaren, P. (2010) 'Teaching against consumer capitalism in the age of commercialization and corporatization of public education'. In J.A. Sandlin and P. McLaren (eds), Critical Pedagogies of Consumption: Living and learning in the shadow of the 'shopocalypse'. Abingdon: Routledge, 84-92.

Schön, D. (1983) The Reflective Practitioner: How professionals think in action. New York: Basic Books.

Schön, D. (1987) Educating the Reflective Practitioner: Toward a new design for teaching and learning in the professions. San Francisco: Jossey-Bass.

Schroth, G., Läderach, P., Martinez-Valle, A.I., Bunn, C. and Jassogne, L. (2016) 'Vulnerability to climate change of cocoa in West Africa: Patterns, opportunities, and limits to adaptation'. Science of the Total Environment, 556, $231-41$. https://doi.org/10.1016/j.scitotenv.2016.03.024.

Solis, H. (2015) 'A story of chocolate and child labor'. Huffington Post, 30 July. Accessed 29 July 2016. https://www. huffpost.com/entry/a-story-of-chocolate-and_b_7899998.

Sterling, S. (2014) 'The importance of education for sustainable development'. University World News, 28 November.

Vare, P. and Scott, W. (2008) 'Education for sustainable development: Two sides and an edge'. DEA Thinkpiece. Accessed 20 August 2021. https://www.academia.edu/21256086/Education_for_Sustainable_Development_two_sides_and_an_ edge.

Vecchio, R. and Annunziata, A. (2015) 'Willingness-to-pay for sustainability-labelled chocolate: An experimental auction approach'. Journal of Cleaner Production, 86, 335-42. https://doi.org/10.1016/j.jclepro.2014.08.006.

Wall, S. (2006) 'An autoethnography on learning about autoethnography'. International Journal of Qualitative Methods, 5 (2), 146-60. https://doi.org/10.1177\%2F160940690600500205.

Wessel, M. and Quist-Wessel, P.F. (2015) 'Cocoa production in West Africa: A review and analysis of recent developments'. NJAS-Wageningen Journal of Life Sciences, 74, 1-7. https://doi.org/10.1016/j.njas.2015.09.001.

Wiek, A., Bernstein, M.J., Laubichler, M., Caniglia, G., Minteer, B. and Lang, D.J. (2013) 'A global classroom for international sustainability education'. Creative Education, 4, 19-28. https://doi.org/10.4236/ce.2013.44A004.

Zembylas, M. (2015) '"Pedagogy of discomfort" and its ethical implications: The tensions of ethical violence in social justice education'. Ethics and Education, 10 (2), 163-74. https://doi.org/10.1080/17449642.2015.1039274.

Zembylas, M. and Boler, M. (2002) 'On the spirit of patriotism: Challenges of a "pedagogy of discomfort"'. Teachers College Record. Accessed 3 June 2021. http://www.tcrecord.org/Content.asp?ContentID=11007. 